\title{
Cattle influence on the population structure of yerba mate (Ilex paraguariensis) in Araucaria Forest
}

\author{
Lilian Iara Bet Stedille ${ }^{1^{*}}$ (D) Edicléa Zulian Pires ${ }^{1}$ (D) Juliano Pereira Gomes ${ }^{1}$ (iD \\ Newton Clóvis Freitas da Costa ${ }^{2}$ (iD) Alison Paulo Bernardi ${ }^{2}$ (D) Adelar Mantovani ${ }^{3}$
}

'Programa de Pós-graduação em Produção Vegetal, Universidade do Estado de Santa Catarina (UDESC), 88520-000, Lages, SC, Brasil. E-mail: lilian.stedille@gmail.com. "Corresponding author.

${ }^{2}$ Programa de Pós-graduação em Recursos Genéticos Vegetais, Universidade Federal de Santa Catarina (UFSC), Florianópolis, SC, Brasil. ${ }^{3}$ Departamento de Engenharia Florestal, Universidade do Estado de Santa Catarina (UDESC), Lages, SC, Brasil.

ABSTRACT: This study characterized the demography and spatial pattern of a yerba mate (Ilex paraguariensis A.St.-Hil) population covering areas with different use histories (Presence and Absence of Cattle) in a Araucaria Forest. Data collection was performed in three ha, half in each area. The frequency of individuals by height, spatial distribution pattern, diameter distribution (for reproductive individuals) and sexual ratio were evaluated. An inverted " $J$ " pattern predominated, being exclusive to an area with Cattle Presence, a place which presented a lower density of individuals. The predominant spatial distribution pattern was aggregated, and the reproductive individuals have a preferentially random pattern at the shortest distances. Results indicated that cattle presence changes the density of I. paraguariensis individuals and the proportion of individuals in the evaluated demographic classes.

Key words: spatial distribution, demographic dynamics, Ripley's K-function.

Influência do gado na estrutura populacional de erva-mate

(Ilex paraguariensis) em Floresta com Araucárias

RESUMO: Foi caracterizada a demografia e o padrão espacial de uma população de erva-mate (Ilex paraguariensis A.St.-Hil) abrangendo áreas em diferentes históricos de uso (presença e ausência de gado), em Floresta com Araucárias. A coleta de dados foi realizada em três ha, metade em cada área. Foi avaliada a frequência de individuos por classe de altura, padrão de distribuição espacial, distribuição diamétrica (para individuos reprodutivos) e razão sexual. O padrão "J" invertido foi predominante, sendo exclusivo para área com presença de gado, local que apresentou uma menor densidade de indivíduos. O padrão de distribuição espacial predominante foi o agregado, sendo que os individuos reprodutivos possuem preferencialmente padrão aleatório nas menores distâncias. Os resultados indicam que a presença do gado altera a densidade de I. paraguariensis e a proporção de indivíduos nas classes demográficas avaliadas.

Palavras-chave: distribuição espacial, dinâmica demográfica, função K de Ripley.

\section{INTRODUCTION}

Ilex paraguariensis A.St.-Hil (yerba mate) is the most relevant species of its kind from an economic perspective, and it presents a high sociocultural importance for the southern region of Brazil (REIS et al., 2018). It is well known and exploited for its stimulant drink and also for formulating drugs and cosmetics. It is a dioecious species native to South America, which mainly colonizes the understory of the Araucaria Forest (AF), a formation belonging to the Atlantic Forest (CABRAL et al., 2018). Its phytophysiognomy has been fragmented and altered by logging and non- timbering operations conducted without ecological criteria or usage management, with only $12.6 \%$ of its original coverage remaining (RIBEIRO et al., 2009; VIBRANS et al., 2011).

Leaves and branches of I. paraguariensis in the Atlantic Forest constitute an important Non-Wood Forest Product (NWFP) from forest extraction (REIS et al., 2018). High exploitation rates occurring in natural areas due to economic instability have caused a significant decline in its populations (SMALL \& CATLING, 2011).

Although, the scientific literature addresses the ecological behavior of the species, few publications describe the demography in natural environments (i.e. CANALEZ et al., 2006; MATTOS, 
2015). Understanding demographic aspects such as height and diameter distribution, density, mortality, recruitment of individuals, the number of reproductive indices and their life cycle (e.g. longevity) can help provide more knowledge on its dynamics in natural populations which are considered basic premises to develop management and conservation strategies (REIS et al., 2018; MONTAGNA et al., 2018). Studies indicated that dispersal and recruitment may be considered determinant for the spatial pattern of plants. In addition, the habitat heterogeneity and other ecological interactions influence the generation of structural and spatial patterns (LARA-ROMERO et al., 2016).

We can highlight intrinsic issues, disturbances and anthropic pressures such as Forest Tropical fragmentation which alter biotic and abiotic environmental factors and thereby influence the population structure and dynamics (RIBEIRO et al., 2009; AVILA et al., 2016). Among anthropogenic actions in forest ecosystems, the impact of extensive cattle (herbivory and trampling) can damage natural regeneration, germination, seedling density, and genetic drift in the long term (ZAMORANOELGUETA et al., 2012). Extensive livestock farming occurs within approximately $50 \%$ of AF fragments in the state of Santa Catarina (VIBRANS et al., 2011).

Extensive cattle can be considered a chronic anthropic disorder in the Planalto Serrano Catarinense (PSC), with the potential to delay forest succession process and cause floristic homogenization in the tree community (DALLABRIDA et al., 2017). In order to increase knowledge about I. paraguariensis ecology and conservation, we aimed to evaluate the demography and the spatial pattern of a population in $\mathrm{AF}$ areas in order to answer the following question: does the presence of cattle influence the populational structure of I. paraguariensis?

\section{MATERIALS AND METHODS}

The study area is located in the AF in the municipality of Urupema, Santa Catarina state, with the approximate elevation of 1350 ma.s.l. The climate of the region is classified as $\mathrm{Cfb}$ and contains Dystrophic Litholic Neosol and humic Alic Cambisol soils (EMBRAPA, 2013). The I. paraguariensis population has different usage histories: a) Cattle Presence - forest with influence of cattle, about 6 individuals.ha ${ }^{-1}$, in which we considered that other anthropogenic activities (logging and NWFP uses) occurred in the last decades; however, in a less expressive way, and were not observed at the time of data collection (27\%50'20"S and $\left.55^{\circ} 27^{\prime} 22^{\prime \prime} \mathrm{W}\right)$; b) Absence of Cattle - forest preserved without anthropic alterations in the last ten years, including the prohibition of NWFP use, inserted in the RPPNE Complexo Serra da Farofa (27 $54^{\prime} 41^{\prime \prime}$ S and 49'52'59'"W). The sampled areas have similar abiotic aspects (geological unit, topographic conditions, solar exposition) and floristic arboreal vegetation. In surveys conducted by MARTINS-RAMOS et al. (2011) and GOMES et al. (2017), the main tree species sampled in region were Myrceugenia euosma (O. Berg) D. Legrand, Siphoneugenareitzii D. Legrand, Drimys angustifolia Miers, Persea willdenovii Kosterm., Myrceugenia oxysepala (Burret) D. Legrand and Kausel, Myrceugenia myrcioides (Cambess.) O. Berg, Cinnamomum amoenum (Nees) Kosterm., Ocotea pulchella (Nees and Mart.) Mez, and the Dicksonia sellowiana Hook.

Six plots $(50 \times 100 \mathrm{~m})$ were installed, half in each area, totaling three hectares in the sample area. All I. paraguariensis individuals were measured for total height $(\mathrm{H})$, and those with height $\geq 1.30 \mathrm{~m}$ were measured for diameter at breast height (DBH). Two evaluations were performed in the Absence of Cattle with a one-year dynamic interval 2011-2012, where individuals with $\mathrm{H}$ less than three meters were measured again. In this same area, sexing of the individuals was performed according to the reproductive structure of the female $(\mathrm{F})$ and male $(\mathrm{M})$ individuals.

Four classes for the description of the demographic structure were defined based on the height of all individuals: class I (plants with $\mathrm{H} \leq 1.3$ $\mathrm{m}$ ), class II (plants with $\mathrm{H}>1.3 \mathrm{~m}$ and $<3.0 \mathrm{~m}$ ), class III (plants with $\mathrm{H} \geq 3.0 \mathrm{~m}$ and $<5 \mathrm{~m}$ ) and class IV (plants with $\mathrm{H} \geq 5.0 \mathrm{~m}$ ). The reproductive ( $\mathrm{M}$ and $\mathrm{F}$ ) subjects for the Absence of Cattle were distributed into new classes according to the $\mathrm{DBH}$, where the frequencies were calculated by the Sturges formula.

From the spatial position of each individual (Cartesian coordinates $\mathrm{x}$ and $\mathrm{y}$ in meters), the spatial distribution pattern was estimated by Ripley's Univariate K-function and included edgecorrections proposed by Ripley (DIGGLE, 2013). To do so, the radius (h) of one meter was used to estimate $\mathrm{k}(\mathrm{h})$ with a maximum distance of $25 \mathrm{~m}$, which corresponds to the half of the smaller side of each plot, and we posteriorly applied the square root transformation (L - estimated) as it is more appropriate for use in simulation envelopes, while deviation from the Complete Spatial Randomness (CSR) was tested by means of the confidence interval (95\%) obtained from 999 Monte Carlo simulations. The analyzes were implemented by the "Splancs" package (ROWLINGSON \& DIGGLE, 1993) in R 
language version 3.2.2 (R DEVELOPMENT CORE TEAM, 2018).

The $\mathrm{H}$ and $\mathrm{DBH}$ averages were compared between the $\mathrm{F}$ and $\mathrm{M}$ individuals by the unpaired t-test, and sex ratio were verified by the chi-squared test $\left(\chi^{2}\right)$. Differences in the proportion of individuals sampled between areas in the same $\mathrm{H}$ class were investigated by the proportions test. The distribution behavior of individuals in the $\mathrm{H}$ classes was verified by the Kolmogorov-Smirnov (K-S) test. These analyzes were performed using the $\mathrm{R}$ program version 3.2.2 ( $\mathrm{R}$ DEVELOPMENT CORE TEAM, 2018).

\section{RESULTS}

\section{Population structure}

The number of individuals per height class and the mean density per area sampled for I. paraguariensis (Figure 1a) were measured.
Significant differences were observed by the K-S test $(\mathrm{P}=0.107)$ for the number of individuals among the $\mathrm{H}$ classes considering the evaluated areas. Thus, there is a difference in the distribution pattern of individuals in the classes for the two evaluated sites.

Figure 1c and 1d show results of frequency distributions of the six evaluated plots. An asymmetric curve can be observed to the right in the form of an inverted " $\mathrm{J}$ " for the Absence of Cattle in all the plots considering the adopted classes, which means that a marked decrease of individuals occurs as there is an increase in the $\mathrm{H}$ classes, and the same pattern was observed in plot 2 for the Absence of Cattle.

\section{Structure of reproductive and dynamic individuals} (Absence of cattle)

Results from monitoring the reproductive stage of the individuals in the Absence of Cattle enabled detection of $2.78 \%$ of the individuals at the

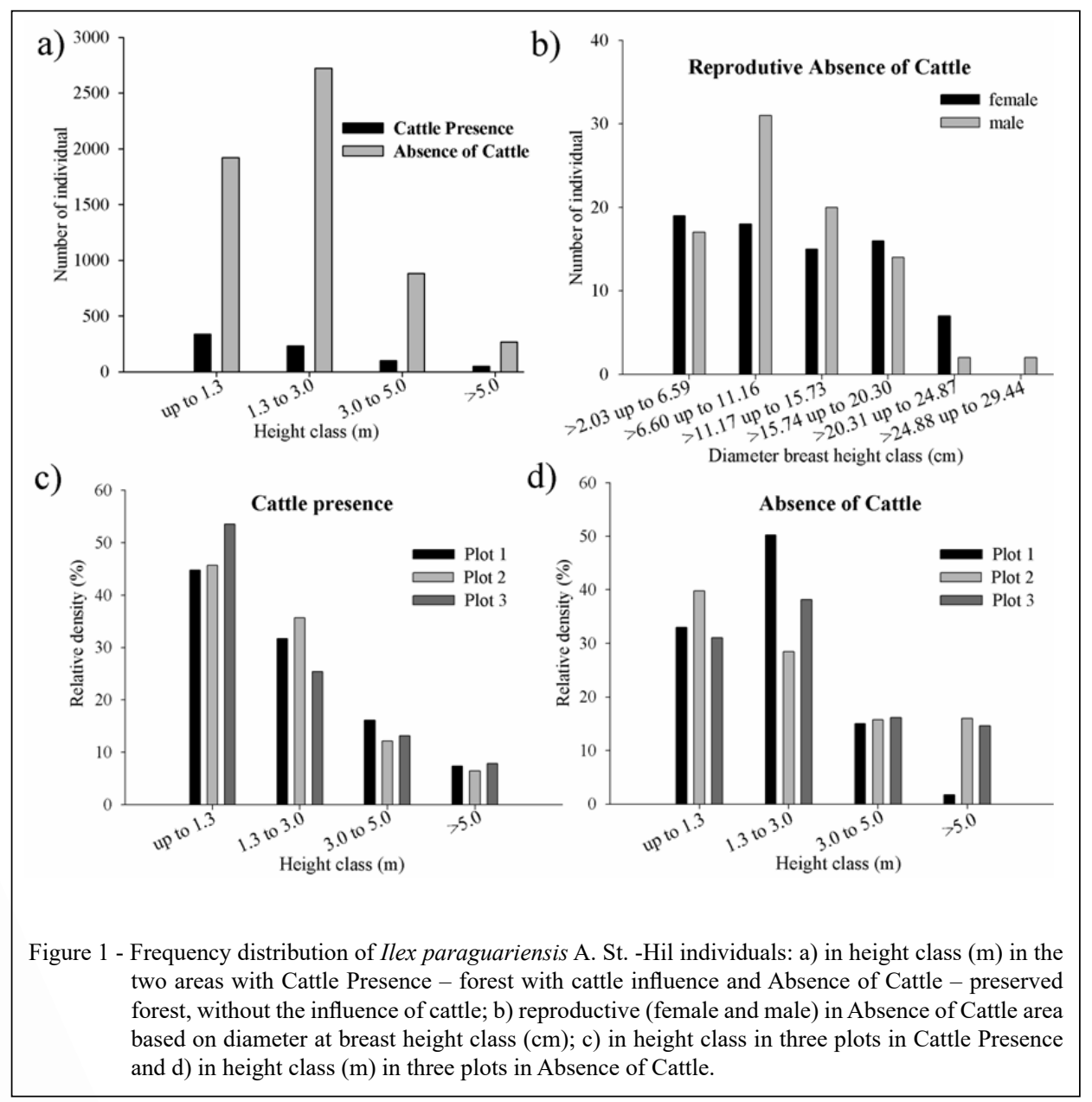

Ciência Rural, v.49, n.11, 2019. 
reproductive stage. Considering the $\mathrm{H}$ classes, a higher proportion of reproductive individuals occurred in class IV, representing $43.07 \%$ of the class (115 individuals), followed by class III where the reproductive ones represented $4.65 \%$ (41 individuals), and class II with only five individuals, representing $0.18 \%$ of the class.

Greater participation of male individuals was observed in the distribution of the reproductive individuals in their respective diametric classes (Figure $1 \mathrm{~b})$ in the class $>6.60$ up to $11.16 \mathrm{~cm}(\mathrm{~F}=18$; $\left.\mathrm{M}=31 ; \chi^{2}=7.04 ; \mathrm{P}<0.05\right)$, and greater participation of female individuals in the class $>20.30$ up to $24.87 \mathrm{~cm}$ $\left(\mathrm{F}=7 ; \mathrm{M}=2 ; \chi^{2}=30.86 ; \mathrm{P}<0.05\right)$.

The mean diameter did not differ statistically between males and females $\left(\mathrm{DBH}_{\mathrm{F}}=11.68\right.$ $\left.\mathrm{cm}, \mathrm{n}=42 ; \mathrm{DBH}_{\mathrm{M}}=11.47 \mathrm{~cm}, \mathrm{n}=44 ; \mathrm{t}=0.83 ; \mathrm{P}>0.05\right)$, while this also occurred for height $\left(\mathrm{H}_{\mathrm{F}}=6.51 \mathrm{~m}, \mathrm{n}\right.$ $\left.=75 ; \mathrm{H}_{\mathrm{M}}=6.08 \mathrm{~m}, \mathrm{n}=86 ; \mathrm{t}=0.25 ; \mathrm{P}>0.05\right)$. The $\mathrm{sex}$ ratio was 1.15 , with no significant difference in the expected ratio of $1: 1$ between males and females in general $\left(86: 75, \chi^{2}=0.47 ; \mathrm{P}>0.05\right)$, and for plots where the following ratios were observed: in plot $1(\mathrm{~F}=20$; $\mathrm{M}=29)$, plot $2(\mathrm{~F}=13 ; \mathrm{M}=12)$ and plot $3(\mathrm{~F}=42 ; \mathrm{M}=45)$.

When considering the evaluation of the dynamics performed in the Absence of Cattle, a total of 56 individuals entering the population were registered, representing less than $1 \%$ in the previous year's evaluation. A mortality rate of 232 individuals (4\% of individuals) was recorded. Of the 232 dead individuals, 175 belonged to class I, and the rest of the individuals belonged to class II. The population from one year to the other generally presented a deficit of 176 individuals.

\section{Spatial pattern}

An analysis of the spatial pattern performed for the six plots showed similar behavior in both plots (Figure 2), with an aggregated pattern best describing the population in a full 25 -meter scale. A random distribution pattern was predominant in the shortest distances for the reproductive individuals in the Absence of Cattle.

\section{DISCUSSION}

\section{Population structure}

Areas under different usage histories tend to vary in the density of individuals according to the intervention intensity as a reflection of the anthropic changes generated to the environment. There was a lower density of I. paraguariensis individuals in this study in the area with Cattle Presence (481 ind. ha-1) compared to the area without cattle (3863 ind. ha-1). In the same way, lower I. paraguariensis densities were observed by MATTOS (2015) for the Planalto Norte Catarinense (PNC) region in environments with cattle presence. In addition to this study, there is exploitation and management of I. paraguariensis populations in most of the AF fragments which contain them in their composition, occurring simultaneously with historical and recent evidence of wood use and presence of extensive cattle (VIBRANS et al., 2011).Thus, the impact caused by cattle trampling is evident, which generates modifications in the structure (density) of I. paraguariensis. This statement was reinforced by our sampling carried out in nearby areas which have similar characteristics, with common arboreal species communities and similar usage history, except for current use with Cattle Presence.

According to the K-S test, the representation of the individuals considering the evaluated demographic classes presented differentiated behavior between areas. The population presents a greater number of individuals in the initial phase of the life cycle for cattle presence (Figure 1c), having an inverted "J" structure pattern. In the Absence of Cattle, a different population structure was observed than in Cattle Presence (Figure 1d), indicating a possible "disequilibrium" in the population structure when compared to the inverted "J" pattern for plots 1 and 3, which presented a larger number of individuals in class II. This finding may be related to the Absence of Cattle history, where the forest was isolated from anthropic alteration sources ten years ago, aiming the conservation of nature and instituted as a conservation unit. In this case, the succession of the environment may have favored germination of the soil seed bank. I. paraguariensis seeds are dormant due to embryo immaturity (DICKEL et al., 2011) and can remain waiting for complete development and favorable germination conditions for long periods. Thus, more favorable periods (i.e. opening of gaps) may have benefited entry and/or maintenance of the individuals in class II. Conversely, this favoring may be related to the elimination of possible causes of anthropogenic degradation (logging and non-timber harvesting, burning, domestic animals, etc.) which negatively influence species development, affect the presence of dispersing agents, seasonality and propagule production. In a study that was developed in different landscape units of I. paraguariensis yerba management and cattle grazing, yerba management and no cattle grazing and no management, REIS et al. (2018) observed demographic peculiarities between and within the evaluated landscape in the PNC. It is also worth mentioning that microhabitat 


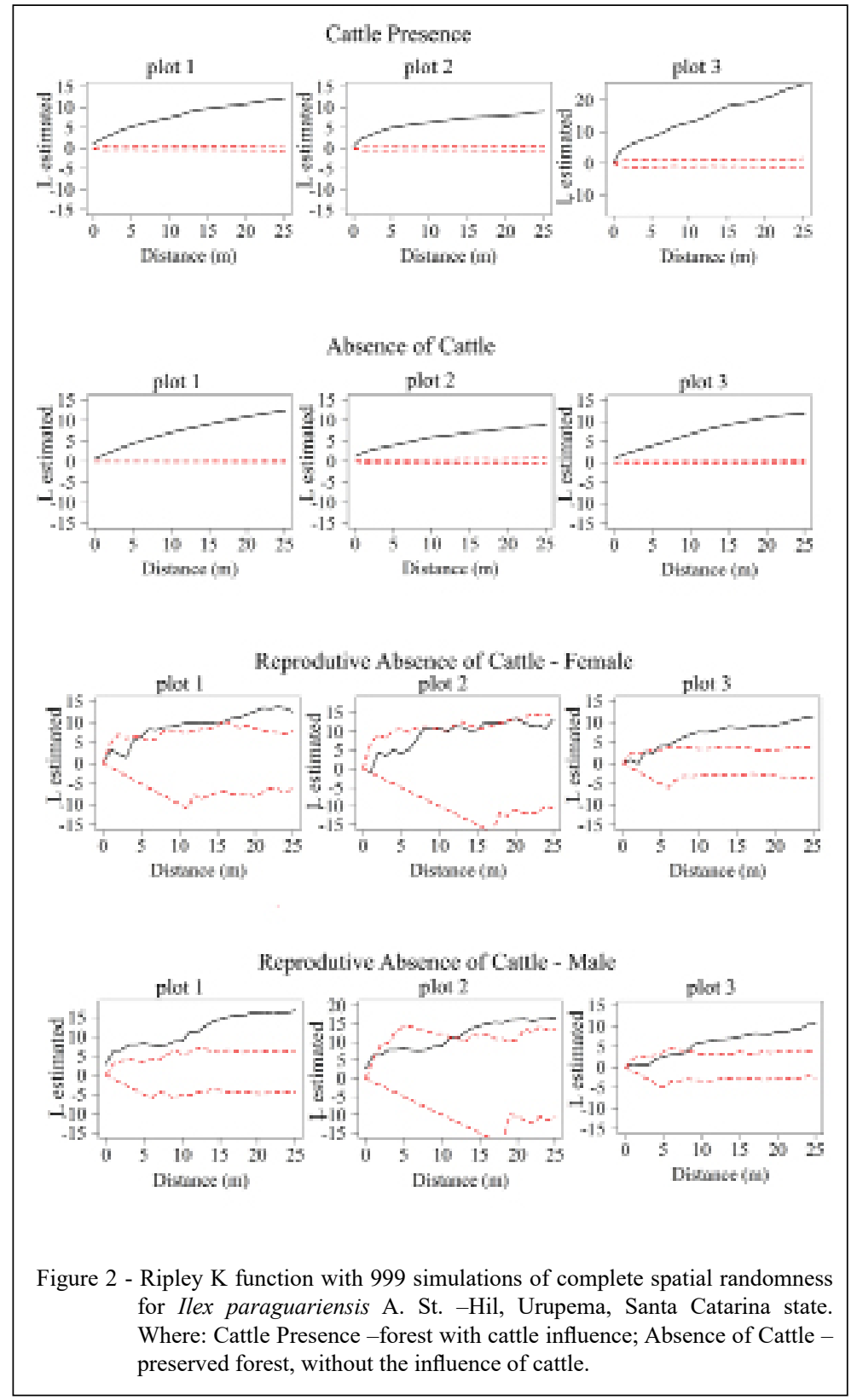

characteristics can influence the development of individuals that make up a population (RODE et al., 2010), and according to AVILA et al. (2016), I. paraguariensis can present a differentiated population structure within the same environment, as well as in the different sampled areas.

The proportions of individuals in class I, class II and class IV differed among sites according to the proportions test $(\mathrm{P}<0.01)$, emphasizing the differences in the population structure in the Presence and Absence of Cattle. These differences may have originated due to several factors such as microclimatic, edaphic conditions, interspecific competition, herbivory, presence of dispersers, or others such as the presence of cattle as investigated in this study. According to DALLABRIDA et al. (2017), cattle presence can be considered a chronic anthropic disturbance for the PSC region, with the potential to delay the process of forest succession, influencing the composition and modifications that occur in the tree communities. The presence of cattle negatively acts on population dynamics due to their herbivorous

Ciência Rural, v.49, n.11, 2019. 
habits, trampling and openings tracks which damage the natural regeneration of the forest (ZAMORANOELGUETA et al., 2012; MATTOS, 2015).

\section{Structure of reproductive individuals and dynamics} (Absence of cattle)

Regardless of sex, the reproductive individuals are mainly distributed in $20.30 \mathrm{~cm}$ of diameter (Figure 1b). Differently from expected, there was a greater participation of male individuals in the class $>6.60$ up to $11.16 \mathrm{~cm}$ and greater participation of female subjects in the class $>20.31$ up to $24.87 \mathrm{~cm}$, which means there is a greater proportion of female individuals in the largest diameters. Female individuals of woody dioecious species usually proportionally allocate more resources for reproduction and defense, and less for maintaining higher growth rates (BARRETT \& HOUGH, 2012). It is evident that female I. paraguariensis trees produce more biomass, and this species possibly presents a different pattern than most woody species (STURION et al.,1995).

When evaluating the dynamics in the Absence of Cattle, the mortality rate was $4.0 \%$ and the majority of the individuals sampled belonged to class I. For CUBAS et al. (2016), I. paraguariensis was the species that presented the highest mortality in the dynamics of a AF, with a mortality rate of $4.20 \%$ (above $10 \mathrm{~cm}$ of $\mathrm{DBH}$ ), but maintained the same position of importance in the forest for five consecutive years with an annual ingrowth introductory rate of $1.86 \%$. According to AVILA et al. (2016), I. paraguariensis has the potential to remain in the environment for a long time, being present in all forest regeneration mechanisms (seed rain, soil seed bank, seedling bank, natural regeneration and arboreal size), and presents population balance in more conservative environments.

\section{Spatial pattern}

Spatial distribution pattern assists in obtaining NWFP in an extractive way, aiming the conservation and use of the species, and facilitating management by aggregating individuals. This same pattern was described in Paraná by RODE et al. (2010), in which spatial aggregation occurs in a distance range of 2 to $38 \mathrm{~m}$ by Ripley's Univariate K-function, and CSR is accepted outside this range. CANALEZ et al. (2006) also reported the same aggregation pattern for I. paraguariensis in AF in Paraná based on the Morisita Index. The spatial pattern of I. paraguariensis is possibly directly related to the associated pollination and dispersal syndrome. Its seeds are pollinated and dispersed by animals (PIRES et al., 2014), common sense the formation of "seed shadows", which means the agent dispersers the propagules and end up eliminating them next to the mother plant.

The aggregated distribution pattern detected in I. paraguariensis can also be considered predominant for tropical trees (RÉJOU-MÉCHAIN et al., 2011). This result comes from two factors, namely the short-dispersal and habitat heterogeneity (LARA-ROMERO et al., 2016).

\section{CONCLUSION}

The presence of cattle changes some demographic characteristics of Ilex paraguariensis, being one of the main factors in reducing the density of individuals and modifies the distribution pattern of the individuals in the height classes. I. paraguariensis has a population structure with a predominance of the inverted " $\mathrm{J}$ " pattern, which was predominant in the cattle presence areas. The predominant spatial distribution pattern for the species was aggregated, except for the reproductive individuals which have a random pattern at the shortest distances.

\section{ACKNOWLEDGEMENTS}

The authors would like to thank the Universidade do Estado de Santa Catarina, the Fundação de Amparo à Pesquisa e Inovação do Estado de Santa Catarina for providing financial support (project FAPESC 2017TR767), and the Coordenação de Aperfeiçoamento de Pessoal de Nível Superior (CAPES) for doctoral scholarships to L.I.B.S, N.C.F.C and A.P.B.

\section{DECLARATION OF CONFLICT OF INTERESTS}

The authors declare no conflict of interests. The founding sponsors had no role in the design of the study; in the collection, analyses, or interpretation of data; in the writing of the manuscript; and in the decision to publish the results.

\section{AUTHORS' CONTRIBUTIONS}

All authors contributed equally for the conception and writing of the manuscript. All authors critically revised the manuscript and approved of the final version.

\section{REFERENCES}

AVILA, A. L. et al. Population structure and regeneration of arboreal species in the national Forest of São Francisco de Paula, Rio Grande do Sul state, Ciência Florestal, v.26, n.3, p.825-838, 2016. Available from: $<$ http://www.scielo.br/pdf/cflo/v26n3/0103-9954-cflo-26-03-00825>. Accessed: Dec. 02, 2018. doi: 10.5902/1980509824211.

BARRETT, S.C.H.; HOUGH, J. Sexual dimorphism in flowering plants. Journal of Experimental Botany, v.64, n.1, p.67 - 82, 2012. Available from: $<$ https://academic.oup.com/jxb/article/64/1/67/63164 1? searchresult=1>. Accessed: Dec. 02, 2018. doi: 10.1093/jxb/ers308. 
CABRAL, A. et al. Aquifoliaceae in the Serra Negra, Minas Gerais, Brazil. Rodriguésia, v.69, n.2, 2018. Available from: <http:// www.scielo.br/pdf/rod/v69n2/2175-7860-rod-69-02-0805.pdf>. Accessed: Sep. 05, 2019. doi: 10.1590/2175-7860201869237.

CANALEZ, G.G. et al. Dynamic of Araucaria angustifolia (Bert.) O. Ktze. e Ilex paraguariensis St. Hil. in two Araucária Forest located in the state of Paraná, Brazil, Ambiência, v.2, n.1, p.9 - 22, 2006. Available from: <http://www.scielo.sa.cr/ scielo.php?script=sci_arttext\&pid=S0034-7442011000300035>. Accessed: Dec. 02, 2018. ISSN 1808 -0251.

CUBAS, R. et al. Increment, ingrowth, mortality in a remnant of Mixed Ombrophyllous Forest in Três Barras, SC state, Ciência Florestal, v.26, n.3, p.889 - 900, 2016. Available from: <http:// www.scielo.br/pdf/cflo/v26n3/0103-9954-cflo-26-03-00889.pdf $>$. Accessed: Dec. 02, 2018. doi: 10.5902/1980509824216.

DALLABRIDA, J.P. et al. Tree component demography in an Upper Montane Mixed Ombrophilous Forest under chronic anthropogenic disturbances. Árvore, v.41, n.3, p.1 - 9, 2017. Available from: <http:// www.scielo.br/pdf/rarv/v41n3/0100-6762-rarv-41-03e410312>. Accessed: Dec. 02, 2018. doi: 10.1590/1806-90882017000300012.

DICKEL, M.L. et al. Ilex paraguariensis - Erva-mate. In: CORADIN, L. et al. Plantas do Futuro - Região Sul. Brasília: Ministério do Meio ambiente, 2011, 934 p.

DIGGLE, P.J. Statistical Analysis of Spatial Point Patterns: Chapman and Hall/CRC, 3. ed. England, 2013. 261 p.

EMPRESA BRASILEIRA DE PESQUISA AGROPECUÁRIA EMBRAPA. Sistema brasileiro de classificação de solos. 3.ed. Brasília, 2013. 353p. Available from: <http://livimagens.sct. embrapa.br/amostras/00053080.pdf $>$. Accessed: Sep. 05, 2019.

GOMES, J.P. et al. Myrtaceae in the Caveiras River Basin: Ecological Characteristics and Non-timber Uses Floresta e Ambiente, v.24, p.1-2, 2017. Available from: $<\mathrm{http}: / / \mathrm{www}$.scielo. br/pdf/floram/v24/2179-8087-floram-2179-8087011115.pdf>. Accessed: Jun. 19, 2019. doi: 10.1590/2179-8087.011115.

LARA-ROMERO, C. et al. What causes conspecific plant aggregation? Disentangling the role of dispersal, habitat heterogeneity and plant-plant interactions. Oikos, v.25, p.1304-1313, 2016. Available from: <https://onlinelibrary.wiley.com/doi/10.1111/ oik.03099>. Accessed: Feb. 26, 2019. doi: 10.1111/oik.03099.

MARTINS-RAMOS, D. et al. Floristics of a remnant of High Montane Mixed Ombrophilous Forest and Grassland, Urupema, Santa Catarina, Brazil. Revista Brasileira de Biociências, v.9, n.2, 156-166, 2011. Available from: <http://www.ufrgs.br/seerbio/ojs/ index.php/rbb/article/view/1524/1033>. Accessed: Jun. 19, 2019.

MATTOS, A.G. Conservação pelo uso de populações de Ilex paraguariensis A. st. - Hil, em sistemas extrativistas no Planalto Norte catarinense. 2015. Tese (Doutorado em Recursos Genéticos Vegetais) - Universidade Federal de Santa Catarina. Available from: $<$ https://core.ac.uk/download/pdf/78550700.pdf $>$. Accessed: Sep. 05, 2019.

MONTAGNA, T. et al. Spatial genetic structure, population dynamics, and spatialpatterns in the distribution of Ocotea catharinensis fromsouthern Brazil:implications for conservation. Can. J. For. Res., v.48, p.1-11, 2018. Available from: <http:// www.nrcresearchpress.com/doi/pdf/10.1139/cjfr-2017-0446>.
Accessed: Feb. 26, 2019. doi: 10.1139/cjfr-2017-0446.

PIRES, E.Z. et al. Biology of erva-mate (Ilex paraguariensis A. St. Hil.) in a remnant of High Montane Mixed Ombrophilous Forest, Revista de Ciências Agroveterinárias, v.13, n.2, p.171-180, 2014. Available from: $<\mathrm{http}: / /$ revistas.udesc.br/index.php/agroveterinaria/ article/view/5631/0>. Accessed: Sep. 05, 2019. ISSN 2238-1171.

$R$ DEVELOPMENT CORE TEAM. R: A language and environment for statistical computing. Available from: $<\mathrm{http}: / /$ www.Rproject.org>. Accessed: Feb. 26, 2018.

REIS, M.S. et al. Domesticated landscapes in Araucaria Forests, Southern Brazil: A Multispecies Local Conservation-by-Use System. Frontiers in Ecology and Evolution, v.6, n.11, p.1-14, 2018. Available from: $<$ https://www.frontiersin.org/articles/10.3389/fevo.2018.00011/ full>. Accessed: Dec. 02, 2018. doi: 10.3389/fevo.2018.00011.

RÉJOU-MÉCHAIN, M. et al. Spatial aggregation of tropical trees at multiple spatial scales. Journal of Ecology, v.99, n.6, 1373 1381, 2011. Available from: <https://besjournals.onlinelibrary. wiley.com/doi/epdf/10.1111/j.1365-2745.2011.01873.x>. Accessed: Dec. 02, 2018. doi: 10.1111/j.1365-2745.2011.01873.x.

RIBEIRO, M.C. et al. The Brazilian Atlantic Forest: How much is left, and how is the remaining forest distributed? Implications for conservation. Biological Conservation, v.142, n.6, p.1141-1153, 2009. Available from: <https://www.sciencedirect.com/science/ article/abs/pii/S00 006320709000974>. Accessed: Dec. 02, 2018. doi: 10.1016/j.biocon.2009.02.021.

RODE, R. et al. Spatial pattern analysis of species and floristic groups established in an Araucaria angustifolia stand and in a Mixed Rain Florest in the center-south of Paraná. Floresta, v.40, n.2, p.255 - 268, 2010. Available from: <https:revistas.ufpr.br/floresa/article/v iew/17821>. Accessed: Dec. 02, 2018. doi: 10.5380/rf.v40i2.17821.

ROWLINGSON, B.; DIGGLE, P. Splancs: spatial point pattern analysis code in S-Plus. Computers and Geosciences, v.19, n.5, p.627 - 655, 1993. Available from: <https:www.sciencedirect.com/ science/article/pii/009830049390099Q>. Accessed: Dec. 02, 2018. doi: 10.1016/0098-3004(93)90099-Q.

SMALL, E.; CATLING, P.M., "Blossoming treasures of biodiversity: 3. Mate (Ilex paraguariensis) - better than Viagra, marijuana, and coffee?" Biodiversity, v.2, p.26 - 27, 2011. Available from: <https://www. tandfonline.com/doi/pdf/10.1080/14888386.2001.97126.75?needAccess =true $>$. Accessed: Dec. 02, 2018. doi: 10.1080/14888386.2001.9712675.

STURION, J.A. et al. Sex ratio and leaf weight production in erva-mate (Ilex paraguariensis St. Hil.). Boletim de Pesquisa Florestal, n.30/31, p.19 - 27, 1995. Available from: <https://ainfo. cnptia.embrapa.br/digital/bitstream/CNPF-2009-09/15535/1/ jsturion.pdf $>$. Accessed: Dec. 02, 2018.

VIBRANS, A. et al. Structure of Mixed Ombrophyllous Forests with Araucaria angustifolia under external stress in Southern Brazil. Biologia Tropical, v.59, p.1371 - 1387, 2011. Available from: $<$ http://www.scielo.sa.cr/pdf/rbt/v59n3/a35v59n3.pdf $>$. Accessed: Dec. 02, 2018. ISSN 0034-7744.

ZAMORANO-ELGUETA, C. et al. Impacts of cattle on the South American temperate forests: Challenges for the conservation of the endangered monkey puzzle tree (Araucaria araucana) in Chile. Biological Conservation, v.152, p.110 - 118, 2012. Available from: <https:// www.sciencedirect.com/science/article/abs/pii/S0006320712001802>. Accessed: Dec. 02, 2018. doi: 10.1016/j.biocon.2012.03.037.

Ciência Rural, v.49, n.11, 2019. 